Buychik, A. (2021). The relevance of the formation of the science of the cultural heritage preservation as the evolution of social and scientific thought. Scientific view on the modern problems of cultural heritage and arts in the context of social development. Klironomy, 1 (1), 7-21. Hlučín-Bobrovníky: "Anisiia Tomanek" OSVČ.

Buychik, A. (2021). Význam formování vědy o zachování kulturního dědictví jako evoluce společenského a vědeckého myšlení. Scientific view on the modern problems of cultural heritage and arts in the context of social development. Klironomy, 1 (1), 7-21. Hlučín-Bobrovníky: “Anisiia Tomanek” OSVČ.

DOI: $10.47451 /$ her2021-06-001

EOI: $10.11249 /$ her2021-06-001

The paper is published in Crossref, Internet Archive, Google Scholar, Academic Resource Index ResearchBib, JGate, ISI, CiteFactor, ICI, eLibrary databases.

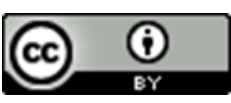

Alexander Buychik Doctor of Economic Sciences, PhD social and political sciences

Chief Director

Klironomy Journal

Tuculart Holding

Ostrava-Hlučín, Czech Republic

E-mail: info@buychik.eu

ORCID: 0000-0002-2542-4198

\title{
The relevance of the formation of the science of the cultural heritage preservation as the evolution of social and scientific thought
}

\section{Abstract:}

Research in the field of cultural heritage preservation has been actively conducted over the past 150 years. The world community has achieved great success in forming a school of objects' restoration and conservation of past civilizations' cultures. However, in the early 21 st century, a lot of knowledge began to go beyond what is already available in the classification of the sciences of art and culture. In the last third of the 20th century, a separate science of restoration began to emerge, which is also looking for its place between culture and art. The need to form a new scientific direction on cultural heritage preservation appeared due to the formation of a huge amount of scientific knowledge, which was supported by the evolution of the philosophical thought of the world-leading thinkers, who came close to defining the Concept of Klironomical Outlook, i.e., structural views on determining the value of cultural heritage. The author justifies that the world community has objectively approached the understanding and separation of the klironomical outlook, which contributes to the formation of a new complex of sciences of the cultural heritage preservation - klironomy. The research used the scientific works of the author of the article, as well as leading experts in the field of culture and philosophers.

Keywords: klironomy, cultural heritage preservation, world community, klironomical outlook.

Alexander Buychik

Dr. ekonomických věd, $\mathrm{PhD}$ sociální a politických věd Generální ředitel 
Časopis "Klironomie"

Tuculart Holding

Ostrava-Hlučín, Czech Republic

E-mail: info@buychik.eu

ORCID: 0000-0002-2542-4198

\title{
Význam formování vědy o zachování kulturního dědictví jako evoluce společenského a vědeckého myšlení
}

\begin{abstract}
Anotace:
Výzkum v oblasti ochrany kulturního dědictví se aktivně provádí za posledních 150 let. Světové společenství učinilo velký pokrok př́i vytváření školy restaurování objektů a zachování kultur minulých civilizací. Na počátku 21. století však mnoho znalostí začalo překračovat to, co je již k dispozici v klasifikaci věd o umění a kultuře. V poslední třetině 20. století začala vznikat samostatná restaurátorská věda, která také hledá své místo mezi kulturou a uměním. Potřebu vzniku nového vědeckého směru na zachování kulturního dědictví vznikly $\mathrm{v}$ souvislosti $\mathrm{s}$ tvorbou velkého množství vědeckých poznatků, že byla posílena vývojem filozofického myšlení předních myslitelů světa, které se těsně přibližil k definici pojmu klironomy pohled na svět, tj. strukturální pohledy na definici hodnoty kulturního dědictví. Autor dokazují, že světové společenství, aby objektivně přišel $\mathrm{k}$ pochopení a rozdělení klironomy tom, že přispívá $\mathrm{k}$ tvorbě nového komplexu věd o zachování kulturního dědictví - клирономии. Studie využívá vědecké práce autora článku, stejně jako předních odborníků v oblasti kultury a filozofů.
\end{abstract}

Kličová slova: klyronomie, zachování kulturního dědictví, světové společenství, klyronomický světonázor.

\section{Introduction}

Research in the field of cultural heritage preservation has been actively conducted over the past 150 years. The world community has achieved great success in forming a school of objects' restoration and conservation of past civilizations' cultures. However, in the early 21 st century, a lot of knowledge began to go beyond what is already available in the classification of the sciences of art and culture. In the last third of the 20th century, a separate science of restoration began to emerge, which is also looking for its place between culture and art.

The need to form a new scientific direction on cultural heritage preservation appeared due to the formation of a huge amount of scientific knowledge, which was supported by the evolution of the philosophical thought of the world-leading thinkers, who came close to defining the Concept of Klironomical Outlook, i.e., structural views on determining the value of cultural heritage [Buychik, 2021; Buychik, 2019, a). Another important reason for this was the formation of four basic directions for the preservation of cultural heritage in various forms - restoration, conservation, renovation and revitalization (Buychik, 2019, b). 
The subject of this study was the evolution of social thought in its temporal representation.

The purpose of the study was to prove the relevance of the formation of a new scientific direction for the preservation of cultural heritage - klironomy.

Based on the purpose of the study, the following tasks were developed:

- analyze the historical prerequisites for the emergence of the klironomical worldview in modern society;

- analyze the evolution of philosophical thought about the value of cultural heritage.

Analytical, historical and logical methods were used to achieve the goals and objectives of the study.

The research used the scientific works of the author of the article, as well as leading experts in the field of culture and philosophers.

\section{Historical prerequisites for the emergence of the klironomical outlook in modern society}

Many drawings, buildings, statues and household items have been created for the last 12 thousand years of human history. We find rock paintings in caves and grottos, the settlement of which took place tens of thousands of years ago. Archaeologists discovered presumably the oldest petroglyphs in the history of humanity, the age of which is about 40 thousand years, on the island of Sulawesi (Buychik, 2019, b). The first urban settlements dating of which are officially recognized by archaeologists belong to the 8th millennium BC. Among them, the settlement of Jericho, or Ariha in Hebrew, is particularly distinguished. It was located on the West Bank of the Jordan River. The first traces of human life in it just belong to that period. The oldest city fortifications were dated by no later than $6800 \mathrm{BC}$ that was the beginning of the 7th millennium BC (Strutin, 2001). Damascus, the modern capital of the Syrian Republic, rivals Jericho by the age of construction of urban structures. The excavations on the outskirts of Tel Ramad indicate that the territory of modern Damascus was inhabited in the 9th or 10th millennium BC (Neolithic Tell Ramad). Damascus may be the oldest urban settlement on the planet.

The first officially known save the object as a particular social, political or cultural value of civilization, i.e., the historically proven fact of the birth klironomical worldview, is a message about the recovery of the Great Sphinx in Giza Valley from the sand. The first mention of the work on the Great Sphinx dates back to about 1400 BC. By that time, the monument was almost completely immersed in the sand. 
According to paleo-climatic studies, it could occur for not less than 1000 years of desolation of the object. Therefore, the Great Sphinx was created no later than 25002400 BC. The first well-known restoration and conservation works of klironomical character were in the reign of Pharaoh Thutmose IV and consisted of three main stages (Buychik, 2014). It was a good example of restoration work, i.e., the complex of klironomical events. In fact, the date $1400 \mathrm{BC}$ can be considered the oldest documented mention of the restoration work, which significantly pushes the historiography of scientific and practical course today.

However, the notion to preserve the values of the past and their destruction was in a kind of symmetry throughout the history of the world's largest civilizations. In fact, the preservation and vandalism in various forms existed in all ages of human development showing a struggle of opposites: klironomy and vandalism. The Ancient Egyptian pharaohs brought down their troops on the territory of the Nubian Kingdom plundering and destroying numerous temples, which were done in response by the rulers of Nubia. Despite mutual vandalism, the rulers of the kingdoms of Ancient Egypt, Nubia, the Sumerian-Akkadian Kingdom, etc. hold a contradictory policy concerning the objects of their cultural heritage, too. They destroyed steles, statues and frescoes of some past undesirable rulers for internal policy. However, at the same time, they took care of the most important monuments that had sacred meaning for civilization. Also, we have some information about the restoration work in the Ancient Egyptian and Sumerian-Akkadian towns.

For a long time, in the Middle Ages and the Renaissance, the attitude to the cultural heritage was indifferent. The beginnings of the world klironomical outlook of society waned. We can see hundreds of paintings by Dutch, German, French and Italian artists of the 15-18th centuries who depicted colourful landscapes and scenes of the life of the different social segments in front of the ruins of past eras, mainly Ancient Roman and Ancient Greek buildings and statues. There is no documentary evidence of any large-scale measures for the preservation or recovery of objects.

During the 11-14th centuries, this attitude could be traced in almost all European countries, including Russia. Analysis of the composition of the stone walls of the medieval fortresses and churches of Novgorod the Great, Pskov, Kyiv and other cities shows that, of course, repair and restoration works were carried out throughout the centuries. However, they also had the character of literal maintenance of objects in proper condition only. Often the repair was carried out with completely different materials and techniques, which was more like the forced minimum actions to keep the object safe than restoration work. 
The Renaissance was marked by a new cultural paradigm that emerged as a result of fundamental changes in social relations in Europe and their rethinking. The concept of Renaissance was introduced by the Italian painter and art historian of the 16th century, Giorgio Vasari, who, in 1550, in his work "Lives of the Painters, Sculptors and Architect", spoke of representatives of Italian art of his era as people who managed to revive ancient traditions, "brought down to their extreme destruction" (Vasari, 1996).

During this period, it was a practice to create art galleries in buildings that had been specially built for it or well suited for their artistic and architectural merits. The Medici family, for example, spent most of their treasury on the creation of galleries. In 1582, the building, built by John Vasari in 1565 for administrative offices, was assigned to the now-famous Uffizi Gallery (Fossi, 2013). The Uffizi building is connected with another famous gallery of Pitti by Ponte Vecchio. Similar gallery complexes began to appear in other cities of the Apennine Peninsula - Pisa, Siena, Verona and Venice - and in major European cities later - in Germany, France, Spain, the Netherlands, Sweden and England. Therefore, all these galleries were created in the name of preservation of already available cultural heritage objects - painting and sculpture. It could be considered the basis for the announcement from the end of the 16th to the beginning of the 17th centuries by the beginning of large-scale activities on preservation of some types of cultural heritage objects: picturesque pictures, frescoes, sculptures and many objects of decorative and applied art, i.e., the forerunner of formation of klironomical outlook.

The period of religious reformation from the 16th to mid-17th century became a turning point and significant in the true preservation of the cultural heritage in the European past. As mentioned above, the first documented restoration work of the Renaissance was carried out with the frescoes of the Sistine Chapel in 1565, at the end of the Renaissance.

In 1726, during the Enlightenment, the artist Michelangelo Bellotti made the first attempt to restore the picture Last Supper of the outstanding painter and scientist Leonardo da Vinci. Already in 1729, the restoration work of Domenico Michelini in Venice with paintings by Titian was described. Then restoration began to be defined as a professional direction, and the profession of "restorer" became more important. In the second third of the 18th century, it became a profession in France, which could be considered an important historical fact in the formation of the klironomical outlook. Almost 85 years, from 1735 to 1820, restoration of paintings of the Spanish Royal Gallery was carried out after the fire of 1734 (Iglesias, 1991). Hundreds of valuable paintings had already been processed according to a 
specially developed technique in a specially built Studio. Zahira Veliz was able to document the materials used in the work (Studies in the History of Painting Restoration, 1998), which helped to differentiate the history of the development of the klironomical direction, i.e., the cultural heritage preservation in three stages at that time.

The 18th century became a fundamental stage in the formation of conservation and restoration activities for cultural heritage preservation, in other words, the formation of the worldview of society. We did not see the attention and care of man about objects and items of the distant past - the oldest civilizations and antiquity in that time. However, archival documents indicated the beginning of the process of caring for the safety of objects and items of the relatively recent past - the last 200300 years, i.e., the Renaissance. Still, based on the ideals of ancient art, neither its creators, nor experts in the emerging field of preservation of art items, nor their customers from the category of wealthy representatives of society did not focus on the restoration of earlier objects and art items.

The Enlightenment was marked by the release of understanding of cultural heritage preservation of the past to a new level - scientific and educational klironomy. It gives reason to highlight the fourth stage in its history and development. This stage can be determined by the period from the early 19th to the early 20th century. These 110-120 years should be divided into two vectors of development works to preserve the legacy of the past:

1) cognitive vector is large-scale research works in southern Europe and North Africa;

2) research vector is large amount of research in the field of physics and chemistry of materials that contribute to the discovery of new effective methods of conservation and restoration of cultural heritage objects (Buychik, 2019, b).

Therefore, during the 18-19th centuries, European society radically transformed its klironomical perception of cultural heritage paying close attention to the development of scientific approaches in the field of conservation and restoration of paintings and monuments. Also, financing of large-scale exploration of ancient civilizations' territories on the subject to find and fix objects and items of the cultural heritage of ancient civilizations and antiquity began.

The modern stage of klironomy development or the preservation of the cultural heritage of the past can have been roughly identifying from 1918 when a conference dedicated to the opening of ancient painting was held in the Russian State (Troitskaya, 1926). The first all-Russian restoration conference was held on March 19-22, 1921 (Central State Archive of Moscow). In fact, society has moved from 
private research to a systematic and regular exchange of experience. After this conference, during 1923-1933, the fourth large-scale restoration of the Great Sphinx of Giza the valley, which was headed by one of the greatest Egyptologists of the first half of 20th-century French expert Emile Bares, held (Buychik, 2019, b). Since 1928, international congresses on modern architecture (CIAM) have been held:

- 1928 - the 1st Congress in the city of Serrate (Switzerland) and the foundation of CIAM;

- 1929 - the 2d Congress in Frankfurt (Germany) where the issues of creating a minimum comfortable home were discussed;

- 1930 - the 3d Congress in Brussels (Belgium) which raised the problem of rational land distribution;

- 1933 - the 4th Congress in Athens (Greece) where the analysis of 33 leading cities did and the Charter of Urban Planning developed;

- 1937 - the 5th Congress in Paris (France), the theme of which was to understand the home as a place of rest;

- 1947 - the 6th Congress in Bridgewater (England) where the main goals of CIAM were confirmed;

- 1949 - the 7th Congress in Bergamo (Italy), which discussed the practical application of the Athens Charter and the creation of a modular urban grid of the CIAM;

- 1951 - the 8th Congress, Addison (USA), which discussed the problems of the central areas of large towns and cities;

- 1953 - the 9th Congress in Aix-en-Provence (France), which discussed the results of the study of human habitation;

- 1956 - 10th Congress in Dubrovnik (Yugoslavia), which also discussed the study of human habitation (Max Risselada and Dirk van den Heuvel, 2005).

The first International Conference on the Study of Scientific Methods for the Study and Preservation of Art Works, in which numerous seminars were, standards of restoration practice, document management and preservation of objects and subjects of cultural heritage defined, was held in Rome on October 13-15, 1930. The famous Athenian Charter, which marked the beginning of the process of globalization of the problem to preserve cultural heritage and marked the modern stage of development of the worldview of society, was declared by the experts on the protection of monuments and historical sites at the Congress in Athens (Greece) in 1931. Since 1934, the training of experts in the field of preservation of objects and items of cultural heritage begins in Europe. 
The Association of Professional Education for Conservation at Harvard University Club became the result of the creation of a network of educational institutions in Europe and the United States in 1984. In parallel, intensive work on the development of scientific theoretical and practical bases was carried out.

During the 20th century, numerous major scientific developments in the field of physics and chemistry of materials, which made a huge contribution to the development of methods of conservation and restoration of the objects and items of cultural heritage, were made. In parallel, there has been a huge number of search and research, conservation and restoration work, among which it is necessary to highlight the following, around the world over the past 100 years.

Thus, in the last 150 years, society has radically changed its attitude to the heritage of the past and began to apply a scientific approach to the preservation and restoration of cultural heritage. The change of thinking, the transition from ignoring of the material past to its delight, and then the realization of the absence of eternity concerning matter conditions and the desire to preserve the beautiful - all of them led to the practical realization of the desire through scientific research, creating a methodology and organization of the educational process to graduate professional workers in the field of restoration and conservation of objects of cultural heritage. All of them is actualized the creation of a new unified scientific direction of klironomy, i.e., cultural heritage preservation, at the beginning of the 21 st century.

\section{Philosophical thought in the formation of a klironomical outlook}

To consider klironomy as a scientific direction of preserving the historical and cultural heritage of society, it is necessary to trace the evolution of philosophical thought about its role in the development of civilization. The consequence of the formation of a qualitatively new state of culture, determined by the interaction of cultures of individual civilizations in the modern era, is the development of the cultural context of the common world space, awareness of the integrity and indivisibility of the world.

In this regard, it is especially important to understand the concept of "values" in the field of culture, which in turn forms the concept of "cultural value", and through it the definition of the category of "cultural heritage", which is based on the totality of cultural values defined by each civilization within the framework of values accepted by this society. Cultural values, being the highest klironomical manifestations of the world's material and spiritual culture, concentrate the centuriesold experience of mankind. They directly perform a transformative function concerning a person and society as a whole. 
The main task of philosophy on Socrates was the rational justification of religious and moral worldview, knowledge of nature; he considered natural philosophy unnecessary and godless. He was a principled enemy of the study of nature. Socrates declared that the operation of the human mind in this direction is godlessness. The philosopher believed that the world is a creation of the great and almighty "deity". It takes divination, not scientific research, to get the gods' instructions as to their will. He followed the instructions of the Delphic Oracle and was advised to do it to his followers (Taylor, 2001).

Democritus took an active part in the dispute about human dignity - about values, i.e., what is most important for a person; a person should live how and in the name of what. He was concerned about current issues: "Are there principles that can be called the highest moral foundations of life, and if there are, what they are?" Democritus showed the desire to defend his social position in a world where are a variety of aspirations, views, interests - the position of the sage who lives by not only wisdom, ideal and intellectual concerns. However, at the same time, he firmly and distinguished, divided and even contrasted the so-called bodily benefits and pleasures, i.e., the spiritual good, which he considered divine. He said that bodily forces and money do not make people happy, but righteousness and multilateral wisdom do it... the bodily beauty of man is something bestial if the mind is not hidden in it (Guthrie, 1979).

In addition, Democritus said that the true virtue in actions should be opposed to speeches about virtue, so a person should accustom oneself to virtuous deeds and actions, and not to speeches about virtue... the true benefactor is not the one who has mined in the retaliation and the one who wants to do kind activities... A person should be ashamed of oneself as much as other people... a law must be in every soul, i.e., not to do anything indecent (Makovelskiy, 1946). In the future, these thoughts became the klironomical forerunner of restorer postulate "do no harm".

Protagoras sees deep differences of people by their social status and professional affiliation in the understanding of "value". It subsequently played an important role in the klironomical worldview formation of the society, because a person defines the properties and value of an object or item individually. For an individual view to become collectively conscious, it is necessary to have a certain initial klironomical education, which will contribute to the collective determination of the value of cultural heritage.

In "Nicomachean Ethics" and "Politics", Aristotle already realistically analyzed problems of morality pointing out that people form notions of good and bliss borrowed with lives that they lead. The philosopher developed categories of good, 
virtue and happiness. He explored the basic concepts of ethics, defined the criteria of moral evaluation while not losing sight of the main vices in society i.e. immoral acts of people. Therefore, Aristotle first created a classification of virtues and vices. Aristotle understood such qualities of personality, which contribute to the realization of good and justice in the process of their realization, by virtues (Ross, 1995). Therefore, concerning the perception and understanding of cultural heritage, Aristotle outlined the deep granules of the personal moral image, which essentially determine the views of the surrounding objects differentiating them according to certain levels of value. If an object is valuable, it is preserved, protected, repaired, restored by a person until its purpose becomes useless.

In addition, "value" is adjacent to the concept of "beauty" in the modern sense. For Plato and Aristotle, the concept of beauty was closely related to the concept of "kalokagatia", which is understood as "beautiful-and-good", i.e., the beauty of the soul and body. For Plato, kalokagatia was a person's ability to choose the best and the most beautiful but not only in the sense of external beauty and in the sense of internal, i.e., morality. For Aristotle to be beautiful is to be virtuous (Losev \& Shestakov, 1965). Thus, the concepts of good and beauty were closely interrelated in Ancient Greece, especially in Plato and Aristotle. Beauty without a moral beginning, i.e., only the outer, did not delight the ancient philosophers as it quickly faded and was not supported from within.

Thus, in the case of objects of art, "value" was defined as a constant rather than a temporal category. Accordingly, such objects become valuable forever, their preservation and restoration pass into the category of good intentions as a single individual of society and society as a whole. The moral category of "value" was restored in the next historical periods and served as a rich material for philosophical fabrications from the 18th to the 20th century.

In the Middle Ages, despite the shift towards the religious perception of value and beauty, klironomical ideas of the deep preserved in its content, and that was a further turn to the sense of beauty, and in the future and to understanding the conservation of this beautiful.

The Renaissance brought to the fore the values of humanism, but the concept of "value" did not take on the meaning of the philosophical category. During this period, art became of great importance, and as a result, there was a cult of Creator. The sacred character is transferred to the creative activity of the person. Anthropocentrism is associated with the cult of beauty that was characteristic of the Renaissance. For example, Nicholas of Cusa (or Nicolaus Cusanus) emphasized the cognitive power of a person ("person is person's mind") likening creativity to the 
divine (Meuthen, 2010; Yamaki, 2001). Leonardo da Vinci creating his works formed throughout his professional activity the concept of "value" (Brown, 1998). He did not realize the greatness of the saving work of previous creators but actively used their skills thereby laying the spiritual foundations of klironomy in the form of a succession of "values".

In modern times, the development of science and new social relations largely determined the basic approach to the consideration of objects and phenomena as values. Francis Bacon concluded that God did not forbid knowledge of nature. On the contrary, God gave a mind that yearns for the knowledge of the universe. People have to understand only that there are two kinds of knowledge - good and evil. A person must use the mind to know created things and four "ghosts" - parent, cave, area and theatre - the impediments to knowledge (Heese, 1968). Practically, according to F. Bacon, knowledge forms the concept of "value"; overcoming "ghosts", a person can know the essence of "things created by God" including human hands because a person is the creation of God.

David Hume took a dual position on the question of "objectivity" of value: on the one hand, he argued that objects in themselves are devoid of any dignity and "they derive their value from effect only", beauty and value are fully correlated with the possibility to cause a "pleasant feeling" in the subject. On the other hand, objects have "their value", there is "valuable in itself" (Flew, 1986). Hume's contribution to the understanding of the concept of value can be considered the most significant in this area of reflection for the entire pre-Kant period. The elucidation of criteria of the moral value of actions and the discernment of "value-for-oneself" and "valueto-another" should recognize among most of Hume's "provocative" steps. The disadvantage of Hume's reasoning was his understanding of the valuable as "natural", which did not allow one to understand the main thing - what is the value of valuable.

We can find fundamentally new dimensions in the concept of values in the works of I. Kant. There were the works "Groundwork of the Metaphysics of Morals" (1785), "Critique of Practical Reason" (1788) and "Critique of Judgment" (1790), in which moral value determined the value of human individuality; and "value-inoneself" became synonymous with personality so the whole world existed for the value of the individual.

Wilhelm Windelband (Rickert, 1929) and Heinrich Rickert, the representatives of the Baden neo-Kantianism School, announced the notion of "value" by the main subject of philosophy. Following them, Max Scheler (Kelly, 1977), Nicolai Hartmann (Kelly, 2011) and other representatives of the phenomenological direction 
absolutized the concept of "value" as a philosophical category and justified the theological doctrine of values.

After the formation of the philosophical understanding of the "value", it became possible to consider the question of understanding the value in the individual areas of social development including "cultural value" or "cultural value", within which there was the cultural heritage of society in its klironomical understanding.

A period of expansion of the axiological approach in the sciences about man, culture and society came at the end of the 19th century and continued to the 20th century. The concepts of "value of culture" and "cultural value" were considered by many famous philosophers and researchers, for example, David Emile Durkheim (Lemert, 2006), John Dewey (Shook, 2000), Friedrich Wilhelm Nietzsche (Deleuze, 2006), Talcott Parsons (Parsons, 1951), Ralph Barton Perry (Perry, 1926), Clyde Kluckhohn (Kluckhohn, 1952) and Fred Strodtbeck (Kluckhohn \& Strodtbeck, 1961).

Therefore, if a person does not begin to evaluate the objects of creation klironomically, not only in materials and labour costs but also in the time continuum, he or she will not be able to save the results of his own creating. Moreover, such a klironomical look at the time in its primitive displays was formed in the era of ancient civilizations when repair works were carried out in the palaces and fortresses. However, in the Enlightenment, the eye was first turned to the objects of cultural heritage, i.e., frescoes and then to the objects, i.e., the restoration of the walls of important buildings. In the future, the search and find of ancient civilizations' artefacts expanded the functions of museums as an institute of the storage and preservation of the past, and then the determination of the value of artefacts based on their historical significance, i.e., social and temporal characteristics.

Both in the case of consideration of changes in the spiritual perception of time and matter in it and the case of analysis of the evolutionary nature of changes in the "value" concept, we conclude that the formation of modern klironomical understanding of "cultural heritage" has passed a complex and centuries-long way of rethinking the place of man in the world around, the coordinate system of time and space where multidimensionality is the most important mechanism to construct aesthetics, morality and culture as a whole.

Thus, world philosophical thought played an important role in the preservation of cultural heritage for the development of civilization. The philosophy has not yet revealed the understanding of "cultural heritage" but the "value" concept and then "cultural value" concept deeply revealed for two millennia. Thanks to the works of philosophers of the 18-19th centuries, the society realized the inevitability of a 
systematic scientific approach to the preservation of objects of the cultural past, conducting numerous international conferences on conservation and restoration, creating professional associations, developing documents and recommendations for the protection and restoration of cultural values. The klironomical ideas that formed as the attitude of society to its history, culture and art, embodied in the forms of the objects of tangible cultural heritage and the elements of intangible heritage over the past 6,000 years, gradually led to philosophical thought about the value of culture through cultural values. These activities made it possible to create a complex klironomical picture of the worldview concerning the cultural heritage preservation of society.

\section{Discussion}

As part of the discussion of the materials of this article, it is proposed to develop the following topics of the formation of the science of preserving cultural heritage:

1. Possible principles of the allocation of klironomical sciences in the sections of tangible and intangible klironomy.

2. Development of the methodology of the science of the preservation of cultural heritage.

\section{Conclusion}

Thus, the world community has objectively approached the understanding and separation of the klironomical outlook, which contributes to the formation of a new complex of sciences of the cultural heritage preservation - klironomy. The complex of klironomical sciences should be based on four areas of cultural heritage preservation - restoration, conservation, renovation and revitalization. The three scientific sections of this complex should be material, non-material and theoretical klironomies, which structure the sciences on the preservation of cultural heritage as clearly as possible.

\section{References:}

Brown, David Alan (1998). Leonardo Da Vinci: Origins of a Genius. Yale University Press.

Buychik, A. (2019, a). Formation of the concepts of cultural, art history and klironomical outlook as the basis for educating a person of culture and art. The Materials of the International Scientific Forum "Education. Science. Culture". In 5 parts. Part 2. International Scientific and Practical Conference "Pedagogy and Psychology in the 
Modern System of Education”: Collection of Scientific Articles, 91-92. Gzhel: GSU. (in Russian)

Buychik, A. (2019, b). Klironomy as a Science of Preservation of Cultural Heritage. LAP Lambert Academic Publishing. Mauritius-France-Germany.

Buychik, A. (2021). The formation of klironomical thinking in the system of the social outlook. Eastern European bumanitarian collection of mini monographs. Collection of Scientific Articles. European Scientific e-Journal, 1 (7), 108-154. Hlučín-Bobrovníky: "Anisiia Tomanek" OSVČ.

Buychik, A. (2014). The story of the restoration of the Great Sphinx in Giza Valley: the relevance of the preservation of world cultural heritage's monuments. Restoration as the Art of Revival of Historical and Cultural Heritage, 158-170. St. Petersburg: Publishing House "SPbCS". (in Russian)

Central State Archive of Moscow. P-1, op. 1, num. 19. (in Russian)

Deleuze, G. (2006). Nietzsche and Philosophy. Trans. Hugh Tomlinson. Athlone Press.

Flew, A. (1986). David Hume: Philosopher of Moral Science. Oxford: Basil Blackwell.

Fossi, G. (2013). Uffiri. Florence: Giunti Editore.

Guthrie, W.K. (1979). A History of Greek Philosophy. The Pre-Socratic tradition from Parmenides to Democritus. Cambridge University Press.

Heese, M. (1968). Francis Bacon's Philosophy of Science. In Vickers, Brian. Essential Articles for the Study of Francis Bacon. Hamden, CT: Archon Books.

Iglesias, H. (1991). El Palacio Real de Madrid, dos tomos. Madrid: Patrimonio Nacional. Kelly, E. (2011). Material Ethics of V alue: Max Scheler and Nicolai Hartmann. Dordrecht: Springer.

Kelly, E. (1977). Max Scheler. Chicago.

Kluckhohn, Clyde (1952). Culture: A Critical Review of Concepts and Definitions. Cambridge, Massachusetts.

Kluckhohn, Florence R., \& Strodtbeck, Fred L. (1961). Variations in Value Orientations. Evanston, IL: Row, Peterson.

Lemert, Ch. (2006). Durkbeim's Ghosts: Cultural Logics and Social Things. Cambridge University Press.

Losev, A.F., Shestakov, V.P. (1965). History of Aesthetic Categories. Moscow. (in Russian)

Makovelskiy, A.O. (1946). Greek atomists. Baku. (in Russian)

Max Risselada and Dirk van den Heuvel (eds.) (2005). TEAM 10 - In Search of a Utopia of the Present - 1953-1981. Rotterdam. 
Meuthen, Erich (2010). Nicholas of Cusa: A Sketch for a Biography. Washington, DC: The Catholic University of America Press.

Neolitbic Tell Ramad. Pre-History and Archaeology Glossary. URL: http://ancientneareast.tripod.com/Ramad.html

Parsons, Talcott (1951). The Social System. New York: The Free Press.

Perry, Ralph Barton (1926). General Theory of V alue. Cambridge: Harvard University Press.

Rickert, H. (1929). Wilhelm Windelband. 2. Aufl. Tübingen.

Shook, J. (2000). Dewey's Empirical Theory of Knowledge and Reality. The Vanderbilt Library of American Philosophy.

Ross, Sir David (1995). Aristotle. 6th ed. Routledge.

Strutin, M. (2001). Discovering Natural Israel.

Studies in the History of Painting Restoration (1998). Ed. Christine Sitwell and Sarah Staniforth. Archetype Publications.

Taylor, C.C.W. (2001). Socrates: A very short introduction. Oxford: Oxford University Press.

Troitskaya, N. (1926). Museum Construction and Revolution. Science and Art, 1. (in Russian)

Vasari, G. (1996). Lives of the Painters, Sculptors and Architects. Vols I and II. Everyman's Library.

Yamaki, Kazuhiko, ed. (2001). Nicholas of Cusa: A Medieval Thinker for the Modern Age. New York: Routledge. 